\title{
Phylogeny of European Anodontini (Bivalvia: Unionidae) with a redescription of Anodonta exulcerata
}

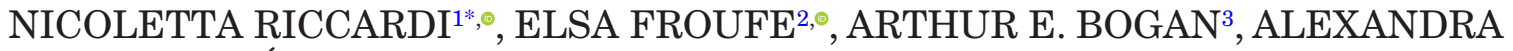 \\ ZIERITZ ${ }^{4}$, AMÍLCAR TEIXEIRA ${ }^{5}$, ISABELLA VANETTI ${ }^{6}$, SIMONE VARANDAS ${ }^{7}$, \\ SERENA ZACCARA ${ }^{6}$, KARL-OTTO NAGEL ${ }^{8}$ and MANUEL LOPES-LIMA ${ }^{2,9,10, \odot}$ \\ ${ }^{1}$ CNR - Institute of Water Research, Verbania Pallanza (VB), Italy \\ ${ }^{2}$ CIIMAR/CIMAR_Interdisciplinary Centre of Marine and Environmental Research, University of \\ Porto, Terminal de Cruzeiros do Porto de Leixões, Avenida General Norton de Matos, S / N 4450-208 \\ Matosinhos, Portugal \\ ${ }^{3}$ North Carolina Museum of Natural Sciences, 11 West Jones St., Raleigh, NC 27601, USA \\ ${ }^{4}$ School of Geography, University of Nottingham, University Park, NG7 2RD, Nottingham, UK \\ ${ }^{5}$ CIMO-ESA-IPB - Mountain Research Centre, School of Agriculture, Polytechnic Institute of Bragança, \\ Campus de Santa Apolónia, Apartado 1172, 5301-854 Bragança, Portugal \\ ${ }^{6}$ DISTA - Department of Theoretical and Applied Sciences, University of Insubria, Varese, Italy \\ ${ }^{7}$ Forestry Department, CITAB-UTAD - Centre for Research and Technology of Agro-Environment and \\ Biological Sciences, University of Trás-os-Montes and Alto Douro, Apartado 1013, 5001-811 Vila Real, \\ Portugal \\ ${ }^{8}$ Senckenberg Forschungsinstitut Frankfurt, Malacology, Senckenberganlage 25, 60325 Frankfurt am \\ Main, Germany \\ ${ }^{9} \mathrm{CIBIO} / \mathrm{InBIO}$ - Research Center in Biodiversity and Genetic Resources, Universidade do Porto, Campus \\ Agrário de Vairão, Rua Padre Armando Quintas, 4485-661 Vairão, Portugal \\ ${ }^{10}$ IUCN SSC Mollusc Specialist Group, c/o IUCN, David Attenborough Building, Pembroke St, \\ Cambridge, $U K$
}

Received 30 July 2019; revised 12 September 2019; accepted for publication 13 October 2019

Freshwater bivalves are highly threatened and globally declining due to multiple anthropogenic impacts, making them important conservation targets. Because conservation policies and actions generally occur at the species level, accurate species identification and delimitation is critical. A recent phylogenetic study of Italian mussel populations revalidated an Anodonta species bringing the number of known European Anodontini from three to four species. The current study contributes to the clarification of the taxonomy and systematics of European Anodontini, using a combination of molecular, morphological and anatomical data, and constructs phylogenies based on complete mitogenomes. A redescription of $A$. exulcerata and a comparative analysis of morphological and anatomical characters with respect to the other two species of Anodonta present in the area are provided. No reliable diagnostic character has emerged from comparative analysis of the morphometric characters of 109 specimens from 16 sites across the Italian peninsula. In fact, the discriminant analysis resulted in a greater probability of correct assignment to the site of origin than to the species. This confirms the difficulties of an uncritical application of visual characters for the delimitation of species, especially for Anodontinae.

KEYWORDS: conservation - freshwater mussels - mitogenome - morphological plasticity - revalidated species.

\section{INTRODUCTION}

Conservation of freshwater mussels (Bivalvia: Unionida) is essential to maintain important ecosystem functions

*Corresponding author. E-mail: nicoletta.riccardi@irsa.cnr.it and services that they provide (Bogan 1993; Lopes-Lima 
et al., 2017a; Vaughn, 2018). Similar to other freshwater taxonomic groups, these bivalves are highly threatened and globally declining due to multiple anthropogenic impacts (e.g. Lopes-Lima et al., 2018, FerreiraRodriguez et al., 2019), raising their conservation importance. However, for many freshwater mussel species, effective conservation measures are hindered by our incomplete understanding of biological species delineations and/or current inability to identify them correctly based on morphology (Prié et al., 2012). This is due to the exceptionally high phenotypic plasticity within freshwater mussel species and morphological convergences between species, reflecting an adaptive phenotypic response to habitat factors (Zieritz \& Aldridge, 2009; Hornback et al., 2010; Zieritz et al, 2010; Reis et al., 2013; Guarneri et al., 2014).

Taxonomic misidentifications are particularly common for species in the tribe Anodontini, because they generally lack diagnostic hinge teeth (Lopes-Lima et al, 2017a). As a result, the Anodontini include some of the most over-described species on the planet (e.g. at least 549 synonyms are available for Anodonta cygnea Linnaeus, 1758; Graf \& Cummings, 2019), whilst morphologically cryptic species have recently been revealed through molecular data in other genera of this tribe (Smith et al., 2018). The Anodontini sensu Froufe et al. (2019) have a Holarctic distribution from western North America to Europe, parts of northern Africa and the Middle East until Transbaikalia [note that Pfeiffer et al. (2019) also include Cristariini sensu Froufe et al. (2019) into Anodontini, with an East Asian/western North American distribution, but because this clade is consistently separated, here we adopt the narrower definition of Lopes-Lima et al. (2017b)].

With increasing molecular sequence data and taxon sampling, the phylogeny and taxonomy of Anodontini have been considerably revised over the past few years, but are still unresolved (Lopes-Lima et al, 2017b; Williams et al., 2017; Smith et al., 2018; Pfeiffer et al., 2019). Current molecular evidence places at least 12 genera in this tribe and an additional two genera (Pegias Simpson, 1900 from North America and Simpsonella Cockerell, 1903 from the Philippines) are usually regarded as Anodontini despite lack of molecular evidence (Lopes-Lima et al., 2017b). Ten of these genera (Alasmidonta Say, 1818, Anodontoides Simpson in F.C. Baker, 1898, Arcidens Simpson, 1900, Lasmigona Rafinesque, 1831, Pseudodontoideus Frierson, 1927, Pyganodon Crosse \& Fischer, 1894, Simpsonaias Say, 1825, Strophitus Rafinesque, 1820, Utterbackia F.C. Baker, 1927 and Utterbackiana Frierson, 1927) are confined to the east coast basins of North America, one (Pseudanodonta Bourguignat, 1877 ) is confined to the Palaearctic and one (Anodonta Lamarck, 1799) is present in the west coast basins of North America, across the Palaearctic, northern Africa and the Middle East. This disjunct distribution of the Anodonta-clade is difficult to explain from a biogeographical perspective and may indicate insufficient character sampling of phylogenies to date, which adopted a two-marker approach (Lopes-Lima et al., 2017b). Next-generation sequencing technology has enabled fast and cost-effective generation of multilocus (phylogenomic) sequence data (McCormack, 2013), but whilst phylogenomics have successfully resolved deep nodes of freshwater mussel phylogenies (Lopes-Lima et al., 2017b; Froufe et al. 2019; Pfeiffer et al. 2019), this tool has yet to be applied to resolve relationships at the tribe level.

In Europe, the total number of Anodontini species is still unknown and, therefore, their phylogenetic relationship remains uncertain (Lopes-Lima et al., 2017a). Until recently, three Anodontini species were recognized in Europe, i.e. Anodonta anatina (Linnaeus, 1758), Anodonta cygnea (Linnaeus, 1758) and Pseudanodonta complanata (Rossmässler, 1835), all with a widespread distribution across the continent, which, in the case of A. anatina, extends to Transbaikalia (Zieritz et al., 2018). Building on preliminary work by Nagel et al. (1996) and Froufe et al. (2014), a fourth species, Anodonta exulcerata Porro, 1838 was recently resurrected by Froufe et al. (2017), based on high genetic distance ( $>8 \%$ in $C O I$ sequence) from its sister-species A. cygnea. Anodonta exulcerata is restricted to Adriatic river basins and delimited by the Italian Alps in the north, Apennine Mountains in the west and Dinaric Alps in the east (Froufe et al., 2017). In addition, the authors confirmed the presence of two genetically distinct $A$. anatina clades: one restricted to the Ebro and Adriatic basins, and one distributed across Europe and parts of Asia except the Iberian Peninsula.

Froufe et al.'s (2017) molecular reassessment resolved uncertainties regarding the identity and number of Anodonta species present in Italy (i.e. A. anatina, A. cygnea and A. exulcerata), which have resulted in several incongruences in the scientific literature, and between national and regional species inventories (Bon \& Mezzavilla, 2000; Bodon et al., 2005; Cosolo, 2008; Autorità di Bacino dei fiumi dell'Alto Adriatico, 2010; Boggero et al., 2016). However, conservation work on the ground, including field surveys, requires the ability to identify species unequivocally through distinguishing morphological (ideally conchological) characters that can be quickly assessed in the field. Unfortunately, no such distinguishing characters are currently known for A. exulcerata, which exhibits strong conchological similarity to both $A$. anatina and A. cygnea.

The phylogenies in Froufe et al. (2017) did not include any member of the Anodonta genus 
from western North America nor the remaining recognized European Anodontini ( $P$. complanata) and was, therefore, limited to reveal the phylogenetic relationships of the European Anodontini. In this context, the aims of this study are to (1) reassess the species diversity, phylogenetic relationships and systematics of European Anodontini using molecular data, (2) unravel the global Anodontini phylogeny using phylogenomics and (3) identify morphometric, morphological and/or anatomical characters to distinguish Italian Anodonta species in the field.

\section{MATERIAL AND METHODS}

\section{SAMPLE COLLECTION}

Anodonta specimens $(N=109)$ were collected from 16 sites across the Italian Peninsula river basins during 2014-16 (Table 1). A small biopsy from the foot was collected in the field (following Naimo et al., 1998) and placed directly into 99\% ethanol for subsequent molecular analysis. Whole specimens were also collected and transported alive to the laboratory for anatomical observations.

All individuals had been barcoded previously for molecular species identification (using COI) published in Froufe et al. (2017).

\section{DNA EXTRACTIONS AND SEQUENCING}

Genomic DNA was extracted from the tissue samples, using a standard high-salt protocol (Sambrook et al.,
1989). F-type mitogenome sequencing and assemblage followed Gan et al. (2014), whilst annotations were performed following Fonseca et al. (2016). All mitogenomes were deposited in the GenBank database under the accession numbers (submitted; Supporting Information, Table S1).

Two datasets were constructed: one for $C O I$ and another for the mitogenomes. The COI dataset included all European Anodontini sequences available in GenBank, with Sinanodonta woodiana (Lea, 1834) and Anemina arcaeformis (Heude, 1877) as outgroups (Supporting Information, Table S2). The mitogenome dataset included all the Anodontini specimens with sequences available from GenBank, with Pseudunio marocanus (Pallary, 1918) as outgroup, plus the eight newly sequenced species: Unio elongatulus (Pfeiffer, 1825), U. mancus (Lamarck, 1819), north-west Iberian lineage Anodonta anatina; A. cygnea; A. exulcerata; $A$. nuttalliana (Lea, 1838); Pseudanodonta complanata and Sinanodonta woodiana (Supporting Information, Table S1). For each dataset, sequences of additional specimens were downloaded from GenBank (details in Supporting Information, Table S1).

The COI dataset was aligned with the MAFFT multiple sequence alignment algorithm (Katoh \& Standley, 2013) and then the final alignment was restricted to its unique haplotypes, using DnaSP v.5.1.0.1 (Librado \& Rozas, 2009).

Mitogenomes were visualized using GenomeVx (Conant \& Wolfe, 2008). Sequences of all mtDNA protein-coding genes (PCG), except ATP8 and the gender-specific open reading frames $(\mathrm{H}-\mathrm{ORF}$

Table 1. Geographic locations of sampled sites, numbers of individuals used in morphometric and molecular analyses, species identified $(A a=A$. anatina $; A c=A$. cygnea; $A e=A$. exulcerata). In the morphometric analysis 29 additional specimens collected by Nagel et al. (1996) were included

\begin{tabular}{|c|c|c|c|c|c|c|}
\hline Catchment & Site & Latitude & Longitude & Morphometrics & mtDNA & Species \\
\hline Po River & Lake Lugano & 45.956475 & 8.965843 & 4 & 4 & $A c$ \\
\hline Po River & Lake Maggiore & 45.980342 & 8.644341 & 51 & 51 & $A c, A a, A e$ \\
\hline Po River & Lake Varese & 45.801208 & 8.736260 & 1 & 1 & $A e$ \\
\hline Po River & Lake Monate & 45.796366 & 8.669498 & - & 2 & $A e$ \\
\hline Po River & Lake Comabbio & 45.767263 & 8.700858 & - & 4 & $A e$ \\
\hline Po River & Lake Viverone & 45.412818 & 8.048182 & 1 & 1 & $A e$ \\
\hline Po River & Lake Candia & 45.321452 & 7.914937 & - & 1 & $A e$ \\
\hline Po River & Lake Annone & 45.814254 & 9.359094 & 1 & 1 & $A e$ \\
\hline Po River & Lake Pusiano & 45.796396 & 9.279407 & - & 1 & $A e$ \\
\hline Po River & Lake Endine & 45.760005 & 9.920562 & 6 & 6 & $A e$ \\
\hline Brenta River & Lake Caldonazzo & 46.005170 & 11.258318 & 3 & 3 & $A e$ \\
\hline Brenta River & Lake Levico & 46.014029 & 11.286210 & 5 & 5 & $A a, A e$ \\
\hline Isonzo River & Isola Morosini (unnamed channel) & 45.763785 & 13.436075 & 2 & 2 & $A e$ \\
\hline Reno River & Lake Castel dell'Alpi & 44.184531 & 11.275864 & 16 & 16 & $A a$ \\
\hline Arno River & Lake Montepulciano & 43.087531 & 11.928983 & 10 & 10 & $A c$ \\
\hline Tiber River & LakeTrasimeno & 43.089545 & 12.153232 & 9 & 9 & $A a, A e$ \\
\hline
\end{tabular}


and F-ORF; Breton et al., 2011), were used in the phylogenetic analyses. The sequences of each gene were aligned using MAFFT software (v.7.304; Katoh \& Standley, 2013) and trimmed with GUIDANCE2 (Sela et al., 2015) following Froufe et al. (2016c). The gene alignments were then concatenated with 12959 nucleotides (nt). PartitionFinder v.2.1.1 software (Lanfear et al., 2016) was used to retrieve the optimal partitioning scheme under the greedy algorithm with proportional branch lengths across partitions. Finally, the best substitution models of DNA evolution for each partition were selected under BIC ranking method (Schwarz, 1978) with both the codon positions of the protein-coding genes and each rRNA being defined as the initial data blocks for the partitioning schemes search. MEGA v.7 (Kumar et al., 2016) was used to estimate the whole mitogenome divergence.

\section{PHYLOGENETIC ANALYSES}

Maximum likelihood (ML) and Bayesian inference (BI) methods were used for all phylogenetic analyses. ML analyses were performed using RAxML (v.8.2.10; Stamatakis, 2014) with 100 rapid bootstrap replicates and $20 \mathrm{ML}$ searches. The BI was applied using MrBayes v.3.2.6 (Ronquist et al., 2012) with two independent runs $\left(10^{7}\right.$ generations with a sampling frequency of one tree for every 100 generations), each with four chains (three hot and one cold). All runs reached convergence (average standard deviation of split frequencies below 0.01). The posterior distribution of trees was summarized in a $50 \%$ majority rule consensus tree (burn-in of 25\%).

For the COI dataset, the models used for BI were: cod 1: K80+I, cod 2: F81, cod 3: HKY+G, while GTR+G was employed for the ML analyses. As for the mitogenome dataset, models used included $\mathrm{GTR}+\mathrm{I}+\mathrm{G}, \mathrm{HKY}+\mathrm{G}$, $\mathrm{SYM}+\mathrm{I}+\mathrm{G}$ and $\mathrm{GTR}+\mathrm{G}$ for the ML analyses.

\section{MOLECULAR-BASED SPECIES DELINEATION METHODS}

Three distinct molecular methods were applied to determine the number of Molecular Operational Taxonomic Units (MOTUs). For the first, i.e. the BIN system implemented in BOLD (Ratnasingham \& Hebert, 2013), the COI dataset was analysed with the Cluster Sequences tool implemented in BOLD 4 (http://v4.boldsystems.org) (Ratnasingham \& Hebert, 2013). The second species delineation method used the $95 \%$ statistical parsimony connection limit in TCS 1.21 (Clement et al., 2000). For the third, i.e. bPTP (Zhang et al., 2013), the BI phylogenies obtained before were used for the input tree. Species delimitation analysis was performed using the python code (available at: www.exelixis-lab.org/software.htm;
Zhang et al., 2013) with $1 \times 10^{6}$ iterations of MCMC and $25 \%$ burn-in.

\section{COMPARATIVE ANATOMY AND CONCHOLOGY}

Morphological analyses of the specimens collected during this study were carried out on shells and living animals. Living specimens were kept in aquaria to observe the external morphology of incurrent, excurrent [anal] and supra-anal apertures. The live specimens were then sacrificed for more comprehensive anatomical and morphological analyses. These included a visual examination of each specimen, noting the shell shape, umbo sculpture and the soft body anatomy (only whole specimens). Digital callipers were used to measure shell dimensions to the nearest $0.1 \mathrm{~mm}$. Shell length was measured as the maximum anterior-posterior dimension of the shell parallel to the hinge ligament. Shell height was the maximum dorsoventral dimension taken perpendicular to the length. Shell width was the maximum lateral dimension, again taken perpendicular to the length. To standardize the variables for size, we calculated the height/length (H/L), width/length (W/L) and width/ height $(\mathrm{W} / \mathrm{H})$ ratios for all specimens. Since the index of convexity $(\mathrm{W} / \mathrm{H})$, which is often used to discriminate between anodontine species, is not independent of shell elongation, it was standardized over length to obtain an independent width-ratio $[(\mathrm{W} / \mathrm{H}) / \mathrm{L}]$. The angle between dorsal margin and posterior margin was measured to the nearest five degrees with a goniometer. The normal distribution was verified for each parameter using the Shapiro-Wilk test optimized for small sample sizes $(N<50)$. Analysis of variance (ANOVA) with a Tukey's test post-hoc comparison on the angle and the H/L, $\mathrm{W} / \mathrm{L}, \mathrm{W} / \mathrm{H}$ and $(\mathrm{W} / \mathrm{H}) / \mathrm{L}$ ratios were performed using StatPlus Pro (6.1.7.5). Discriminant analysis (DA) was then employed to assess how accurately individual shells had been assigned to the genetically identified species.

\section{SHELL MORPHOMETRY}

For a geometric-morphometric analysis of inter- and intraspecific variation in shell morphology of the Anodonta species native to Italy, we used the Fourier shape analysis, as developed and explained by Crampton \& Haines (1996). This method decomposes xy-coordinates of a shell outline into a number of harmonics, each of which is in turn explained by two Fourier coefficients. We analysed 109 specimens collected by the authors (Table 1 ) and 29 specimens collected by Nagel et al. (1996). The xy-coordinates of the sagittal shell outline of each specimen were obtained from digital photographs using the program 
IMAGEJ (Rasband, 2008) and subjected to fast Fourier transformation using the program HANGLE, applying a minimum smoothing normalization of 2 to eliminate high-frequency pixel noise. Preliminary analysis indicated that the first ten harmonics described the outlines with sufficiently high precision. Discarding of the first harmonic, which does not contain any shape information, resulted in a set of 18 Fourier coefficients per individual. After rotating outlines to maximum overlap by program HTREE, principal component analysis (PCA) was performed on the 18 Fourier coefficients using the program PAST (Hammer \& Harper, 2006). The number of principal components to be retained was determined using the broken stick model of the scree plot. Synthetic outlines of extreme and average shell shapes were drawn using program HCURVE as explained in Crampton \& Haines (1996).

To test for statistically significant differences in sagittal shell shape between species, separate ANOVA were run on each of the significant principal components, fitting species as a factor with three levels. Tukey's post hoc test was performed to identify significant differences between each population pair. Finally, we assessed the rate of accurate species identification based on the Fourier Shape Analysis using DA on the set of 18 Fourier coefficients. Statistical analyses were performed in R.3.1.1.

\section{RESULTS}

\section{MOLECULAR PHYLOGENY AND SPECIES DELINEATION}

The haplotype COI alignment is 567 nucleotides long and includes 143 haplotypes (including two as outgroup). The best ML and BI trees retrieved have similar topologies, thus only the BI is shown in Figure 1. As previously reported (Froufe et al., 2017), A. exulcerata clusters with A. cygnea in a well-supported clade. All the A. anatina COI clades are grouped in another well-supported clade, while the phylogenies failed to cluster P. complanata with support (Fig. 1). All three species delineation methods applied retrieved the same results, i.e. identifying the following MOTUs: A. cygnea, A. exulcerata, $P$. complanata and four within A. anatina (Fig. 1).

The length of the newly sequenced mitogenomes is within the expected F-type range of the freshwater mussels, and all present the same previously described gene order, UF1 (Lopes-Lima et al., 2017c). Their main characteristics, i.e. size, gene composition and order, morphological features of the lectotype and paratype (Supporting Information, Figs S1, S2) of representative specimens (Supporting Information, Fig. S3) and of the specimens examined for this study are shown in the Supporting Information, Figures S4-S9 and in Table S3. The best ML and BI trees retrieved have similar

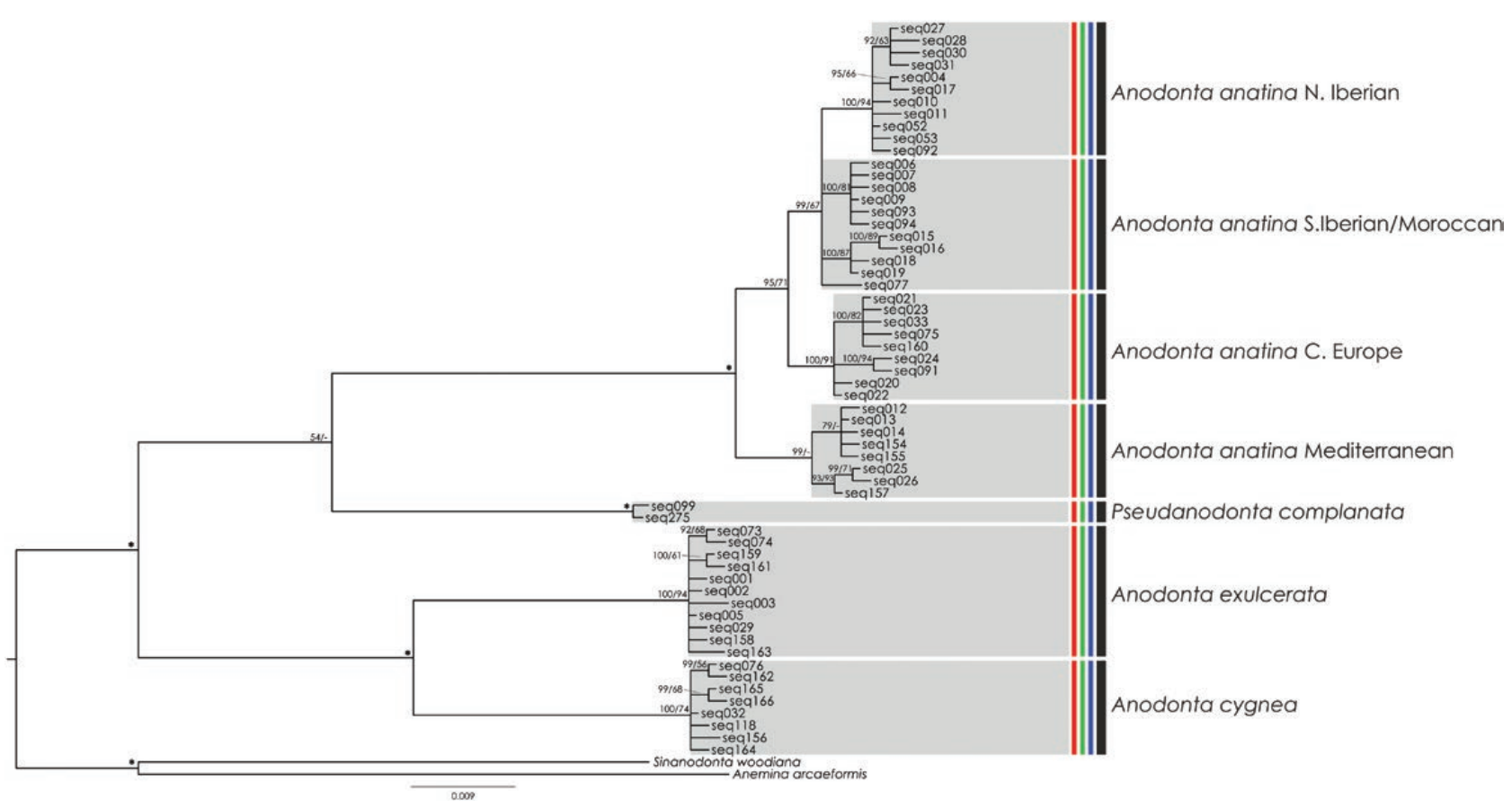

Figure 1. Anodontini phylogenetic trees obtained by Bayesian inference (BI) and maximum likelihood (ML) analyses of the cytochrome $c$ oxidase I (COI) gene fragment. The values nodes indicate Bayesian posterior probability percentage / maximum likelihood bootstrap values, respectively. Values over $95 \%$ are represented by an asterisk. Vertical bars correspond to molecular operational taxonomic units by various species delimitation methods: red - BINS of BOLD; green - TCS (95\%); blue - bPTP; black - consensus. 
topologies, with the exception of the phylogenetic relationship of the Lanceolaria sp. clade. The phylogenomic tree shows the monophyly of Anodontini and its sister-status to the Cristariini clade (Fig. 2). The genus Anodonta is not monophyletic due to the paraphyletic positions of $A$. anatina, $P$. complanata, A. nuttalliana and A. cygnea + A. exulcerata clades (Fig. 2 ). As expected, the phylogenomics also joins $A$. cygnea with $A$. exulcerata with high support. $P$-distance between these two species was $10 \%$ for the whole mitogenome (Supporting Information, Table S4).

\section{COMPARATIVE ANATOMY AND CONCHOLOGY}

\section{Soft tissues morphology}

The inner and outer gills have the same form and size across the three taxa (i.e. A. anatina, A. cygnea and A. exulcerata). The form and size of labial palps are similar in the three species. Main interspecific differences are only found in the papillae morphology of the incurrent aperture and in the pigmentation of the mantle surface in the excurrent aperture (Supporting Information, Fig. S4), characters that were proposed for reliably separating other mussel species (Glöer \& Meier-Brook, 2003; Sayenko, 2007; Sayenko et al., 2009). In the present study, A. anatina can be reliably discriminated from other Anodonta species by internal morphology only in living specimens through its apertural anatomy. Compared to other Anodonta species, A. anatina exhibits a longer excurrent aperture, a greater protrusion of papillae from the edge of the shell and a brownish colour of mantle edge and papillae (Supporting Information, Fig. S4). In contrast, the apertural anatomy of A. exulcerata and A. cygnea is similar and characterized by a short excurrent aperture without marginal and papillae coloration. Living or freshly dissected $A$. exulcerata and A. cygnea specimens present a clearly irregular tan band at the insertion of papillae (Supporting Information, Figs S4, S5). The papillae show a distinct pattern, being arranged in four or five series in A. anatina (four series in 81 and five in $19 \%$ of the specimens), only two or three series in A. cygnea (two series in $27 \%$ and three in $73 \%$ of the specimens) and in A. exulcerata (two series in $42 \%$ and three in $58 \%$ of the specimens).

Another discriminant character is foot and mantle colour, which has been shown to be useful to differentiate A. cygnea from A. anatina (Mordan \& Woodward, 1990; Mezhzherin et al., 2014). Indeed, A. anatina and A. exulcerata present a light-brown/ creamy-white colour, whereas A. cygnea is generally bright-orange coloured (Supporting Information, Fig. S6).

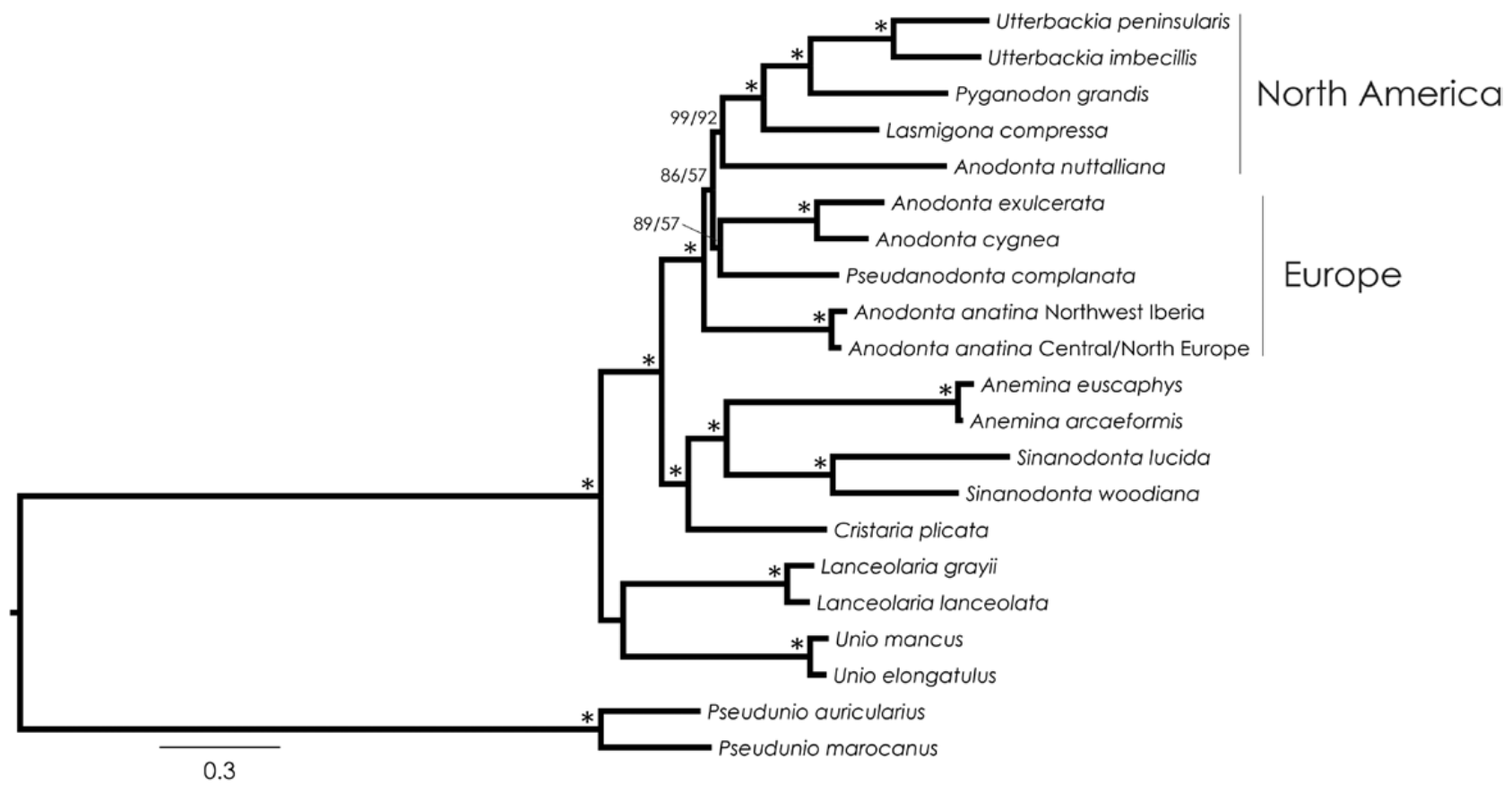

Figure 2. Unionida phylogenetic tree obtained by Bayesian inference (BI) and maximum likelihood (ML) analyses estimated from 14 concatenated individual mtDNA gene sequences (12 protein-coding and two rRNA genes). The values nodes indicate Bayesian posterior probability percentage / maximum likelihood bootstrap values, respectively. Values over $95 \%$ are represented by an asterisk. 
Table 2. Biometric measurements (mean $\pm \mathrm{SD}$, range in brackets) of A. exulcerata, A. cygnea and A. anatina shells

\begin{tabular}{llll}
\hline & A. exulcerata & A. cygnea & A. anatina \\
\hline Length $(\mathrm{mm})$ of shell & $82.82 \pm 10.78(65.41-103.77)$ & $126.39 \pm 31.52(82.05-168.41)$ & $95.66 \pm 17.69(65.93-152.92)$ \\
Height $(\mathrm{mm})$ of shell & $48.11 \pm 6.10(38.48-58.56)$ & $72.71 \pm 18.40(46.66-98.11)$ & $54.45 \pm 8.20(41.55-79.81)$ \\
Width $(\mathrm{mm})$ of shell & $29.08 \pm 5.87(19.52-41.13)$ & $45.31 \pm 16.43(23.29-68.16)$ & $32.82 \pm 8.87(21.30-65.26)$ \\
$\mathrm{H} / \mathrm{L}$ & $0.58 \pm 0.02(0.53-0.63)$ & $0.57 \pm 0.02(0.54-0.61)$ & $0.57 \pm 0.03(0.51-0.63)$ \\
W/L & $0.35 \pm 0.05(0.26-0.45)$ & $0.35 \pm 0.05(0.26-0.41)$ & $0.34 \pm 0.05(0.27-0.43)$ \\
W/H & $0.60 \pm 0.08(0.47-0.76)$ & $0.61 \pm 0.08(0.44-0.72)$ & $0.58 \pm 0.12(0.45-0.82)$ \\
$(\mathrm{W} / \mathrm{H}) / \mathrm{L}$ & $0.007 \pm 0.001^{* *}(0.006-0.010)$ & $0.005 \pm 0.0009^{* *}(0.004-0.007)$ & $0.006 \pm 0.001^{* *}(0.005-0.010)$ \\
Angle $\left(^{\circ}\right)$ between & $135 \pm 6(124-147)$ & $144 \pm 9 * *(116-153)$ & $136 \pm 7(115-148)$ \\
$\quad$ dorsal and posterior & & & \\
$\quad$ margin & & & \\
\hline
\end{tabular}

** $P<0.0001$.

\section{Umbonal sculpture}

Anodonta cygnea umbo sculpture consists of thin concentric lines, while $A$. anatina presents wavy rugae (Supporting Information, Fig. S6). Anodonta exulcerata is more similar to $A$. anatina than to A. cygnea (Supporting Information, Fig. S6), generally presenting wavy rugae. Rugae in $A$. exulcerata, and especially in $A$. anatina, are thicker and more widely spaced when compared to A. cygnea.

\section{Shell morphometry}

\section{Linear morphometric analysis}

Analyses of morphometric shell indexes H/L, W/L, W/H shows substantial intraspecific variability, with a wide overlap between the three species. The only two indexes with discriminating value are the angle between dorsal and posterior margin, and the convexity index standardized by length. Both the angle (ANOVA: $\mathrm{F}=10.9122, \mathrm{df}=2, P<0.001)$ and the standardized convexity index (ANOVA: $\mathrm{F}=30.382$, $\mathrm{df}=2, P<0.001$ ) are significantly different among species. While the standardized convexity index is significantly different among the three species (Tukey's pairwise comparisons significant at $<0.05$ level), differences in the angle are only significant between $A$. cygnea and each of the other two species, but not significant between $A$. anatina and A. exulcerata. However, the wide intraspecific variability of biometric parameters (Table 2) does not allow a reliable discrimination of these species, displaying largely overlapping characters. The PCA eigen-values describe $>99 \%$ of the total variability between species. The PC1 axis describes $97.3 \%$ and the PC2 axis describes $2.97 \%$ of the total variation (Fig. 3A, B). The first component is mainly weighted by lateral inflation and width of the angle between dorsal and posterior margin. The PCA, with group assigned by species, shows a wide morphological range for all species (Fig. 3A) with a large overlap of the three species clusters, including $82 \%$ of the total individuals. The limited usefulness of the biometric characters is confirmed by the discriminant analysis (Table 3) with only $67 \%$ of the specimens being correctly assigned to each species. The major contributors to the principal discriminant factor are the angle between the dorsal and posterior margins and the index of convexity standardized by length (Fig. 3B). The more obtuse angle and the lower lateral inflation of $A$. cygnea (Table 2) allow a $90 \%$ correct assignment, with the remaining $10 \%$ of specimens being misidentified as A. exulcerata. Conversely, $A$. anatina is the most misidentified with $28 \%$ and $18 \%$ erroneous assignments to A. exulcerata and $A$. cygnea, respectively.

\section{Geometric morphometric analysis}

The first two principal components obtained by the PCA on the 18 Fourier coefficients are retained by the broken stick model, and together explain $38 \%$ of the total variance in sagittal shell shape (Fig. 4). The three Anodonta species overlap considerably in their sagittal shell shape, so that PC1 values are not significantly different between any of the three species pairs (ANOVA: $\mathrm{F}=2.665$, $\mathrm{df}=2, P=0.0733$ ). However, PC2 values are significantly different among species (ANOVA: $\mathrm{F}=41.86$, df $=2, P<0.0001$ ), with significant differences between all three pairs of species (Tukey's pairwise comparisons significant at $<0.05$ level). As illustrated by synthetic outlines of extreme shell forms in the PCA plot, A. anatina shells tend to have a more triangular outline with a more developed wing and straighter ventral margin than A. exulcerata and A. cygnea (Fig. 4). A large proportion of the A. cygnea specimens included in our dataset display a particularly convex dorsal margin and pointed posterior margin.

Despite the statistically significant differences in PC2 scores between all three Italian Anodonta species, the power of discriminating A. exulcerata from the other two Anodonta species based on shell shape is relatively poor. Thus, only $71 \%$ of specimens are assigned to 
Table 3. Confusion matrix of Disciminant Analysis of biometric variables (angle; H/L; W/L; Wmax/Hmax; Wmax/Hmax/L) of Italian Anodonta specimens, showing the proportion of specimens correctly/incorrectly assigned to each species (based on 87 specimens; specimens with broken shells were omitted)

\begin{tabular}{lccccc}
\hline Species & \multicolumn{3}{c}{ Predicted group } \\
\cline { 2 - 6 } Given group & A. anatina & A. cygnea & A. exulcerata & Total & $\%$ correct \\
\hline A. anatina & 21 & 7 & 11 & 39 & 54 \\
A. cygnea & 0 & 19 & 2 & 21 & 90 \\
A. exulcerata & 5 & 4 & 37 & 87 & 67 \\
Total & 17 & 33 & & & 27 \\
\hline
\end{tabular}
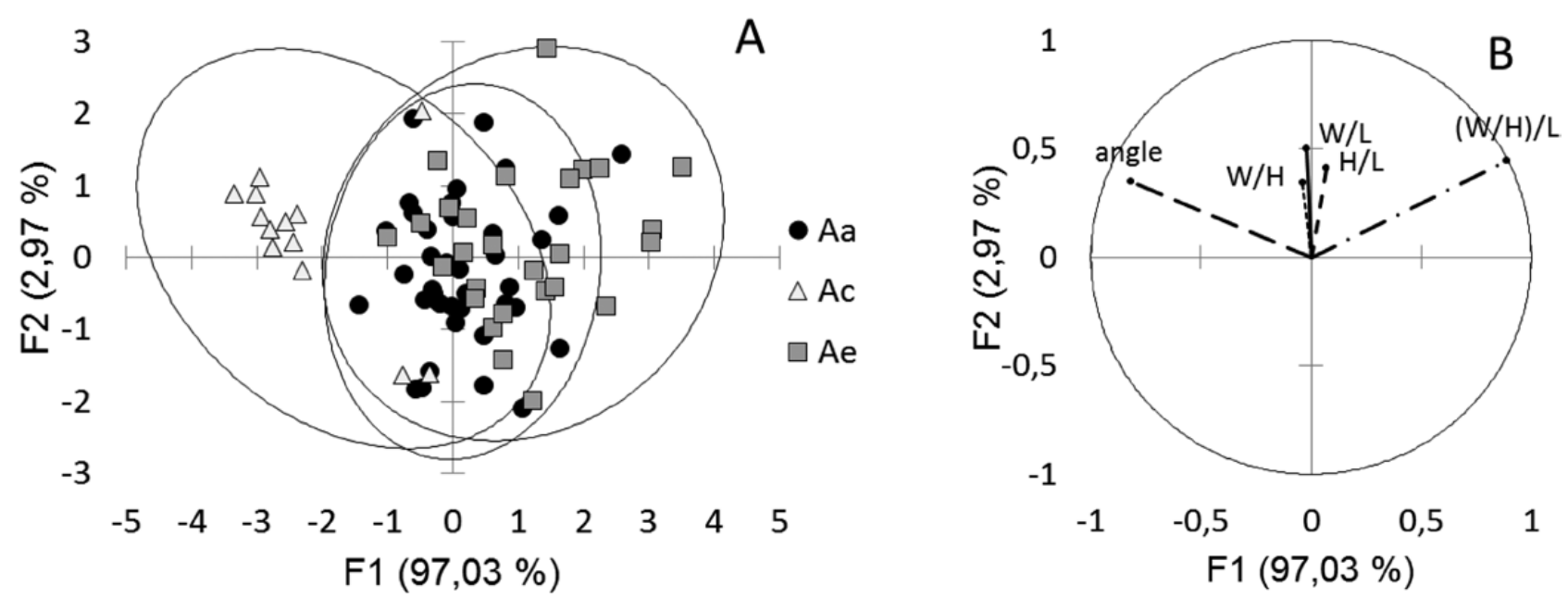

Figure 3. Scatterplot and 95\% confidence ellipses of 108 specimens comprising three Anodonta species collected from sites in Italy displaying the first two principal component scores obtained by discriminant analysis based on linear biometric values. $\mathrm{Aa}=$ A. anatina $; \mathrm{Ac}=A$. cygnea $; \mathrm{Ae}=$ A. exulcerata $. \mathrm{W} / \mathrm{H}=$ width/height; $\mathrm{H} / \mathrm{L}=$ height/length; $\mathrm{W} / \mathrm{L}=$ width/length; $\mathrm{W} / \mathrm{H}=$ width/height ratios; $[(\mathrm{W} / \mathrm{H}) / \mathrm{L}]=$ index of convexity standardized over length; angle = measure of the angle formed by lines tangent to the posterior and dorsal margins.

the correct species based on DA of the morphometric dataset (Table 4A). While the discrimination between A. anatina and A. cygnea in this respect was reliable, both of these species were often misidentified as A. exulcerata and vice versa. As a result, the proportion of correctly identified specimens is particularly low for A. cygnea (59\%), but also far from satisfactory for A. exulcerata $(67 \%)$ and A. anatina $(80 \%)$. On the other hand, the morphometric dataset is relatively powerful in correctly assigning specimens to sites of collection, as $81 \%$ of specimens are correctly assigned to their site non-regarding the species (Table 4B).

A complete redescription of the species is presented in the systematics section below.

\section{DISCUSSION}

Anodontini is consistently retrieved as monophyletic, encompassing several North American genera along with Anodonta and Pseudanodonta species (LopesLima et al. 2017b; Williams et al., 2017). In the most recent classification systems for Europe and North America, the Anodonta genus included two to four species (Anodonta californiensis Lea, 1852,A. kennerlyi Lea, 1860, A. nuttalliana Lea, 1838 and A. oregonensis Lea, 1838) restricted to western North America (Williams et al., 2017) and three species (Anodonta anatina, A. cygnea and A. exulcerata) present in Europe (Froufe et al., 2017; Lopes-Lima et al., 2017b). However, their phylogenetic relationships are still unresolved. The first comprehensive synthesis of the global unionoid fauna placed many North American species in the genus Anodonta (Simpson 1900, 1914). Since then, all eastern North American Anodonta species have been reassigned to other genera (e.g. Pyganodon, Utterbackia, Utterbackiana; Williams et al., 2017). However, western North American species are still considered to belong to Anodonta, but their phylogenetic relationship with European 
Table 4. Voucher specimens of A. exulcerata; MZUF = Museo de La Specola-Florence, NMBE = Naturhistorisches Museum der Bürgergemeinde-Bern, NCSM = North Carolina Museum of Natural Sciences

\begin{tabular}{|c|c|c|c|c|c|}
\hline Catalog Number & locality & Latitude & Longitude & river basin & shell length (mm) \\
\hline MZUF GC/51405 & Lake Maggiore & $45^{\circ} 50 ’ 59.9 " \mathrm{~N}$ & $8^{\circ} 37^{\prime} 06.9 ” \mathrm{E}$ & Po & 97.25 \\
\hline MZUF GC/51406 & Lake Levico & $46^{\circ} 00^{\prime} 31.7^{\prime \prime} \mathrm{N}$ & $11^{\circ} 17^{\prime} 06.5^{\prime \prime E}$ & Brenta & 72.61 \\
\hline NMBE 549733 & Lake Maggiore & $46^{\circ} 08^{\prime} 55.9^{\prime \prime} \mathrm{N}$ & $8^{\circ} 51 ’ 32.2 ” \mathrm{E}$ & Po & 89.80 \\
\hline NMBE 549734 & Lake Caldonazzo & $46^{\circ} 00^{\prime} 25.5^{\prime \prime} \mathrm{N}$ & $11^{\circ} 15^{\prime} 53.1^{\prime \prime} \mathrm{E}$ & Brenta & 82.96 \\
\hline NCSM 102851 & Lake Maggiore & $45^{\circ} 50^{\prime} 59.9 ” \mathrm{~N}$ & 837’06.9”E & Po & 86.22 \\
\hline NCSM 102852 & Lake Caldonazzo & $46^{\circ} 00^{\prime} 25.5^{\prime \prime} \mathrm{N}$ & $11^{\circ} 15^{\prime} 53.1 ” \mathrm{E}$ & Brenta & 80.49 \\
\hline
\end{tabular}

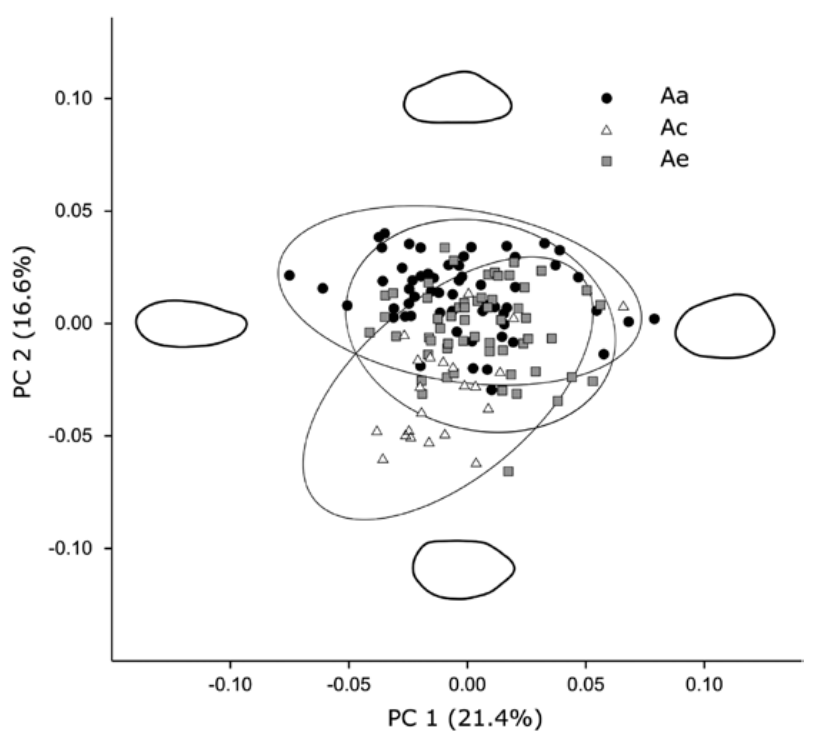

Figure 4. Scatterplot and $95 \%$ confidence ellipses of 138 specimens comprising three Anodonta species collected from sites in Italy displaying the first two principal component scores obtained by principal component analysis of 18 Fourier coefficients. Synthetic shell outlines of 'extreme' morphotypes are displayed with the anterior margin facing to the left and the dorsal margin to the top of the page. $\mathrm{Aa}=A$. anatina $; \mathrm{Ac}=A$. cygnea $; \mathrm{Ae}=A$. exulcerata .

congeneric species remains contentious (Chong et al., 2008; Blevins et al., 2017; Lopes-Lima et al., 2017b). Until now, the phylogenetic position of A. nuttalliana, based on a two-marker approach, clustered with the two European Anodonta species, i.e. A. anatina and A. cygnea (Lopes-Lima et al.,2017b). However, in the present study, this species clusters for the first time with all eastern North American Anodontini species, suggesting a separation from Anodonta and the need for future multimarker molecular studies including the other western North American Anodontini. As for the European species, the results of the first mitogenome analysis confirms the close relationship between A. cygnea and A. exulcerata but suggest that A. anatina is not congeneric. Furthermore, the status of Pseudanodonta is not conclusive (Fig. 2). Again, the inclusion of more taxa and/or nuclear molecular markers is needed to solve this issue.

The three species delineation methods applied here suggest the division of A. anatina into four separate species. However, due to the low divergence levels seen in the $C O I$ uncorrected $p$-distance among these clades (between 1.7\% and 3.7\%) and lack of sampling in some regions (e.g. south-eastern Europe and Tunisia), we refrained from drawing taxonomic conclusions. These should be addressed in the future using a holistic approach, i.e. combining multimarker molecular analyses with morphological, ecological and biogeographical parameters. The present study confirms the species status of $A$. exulcerata based on the high genetic unc- $p$ divergence $(8.5 \%$ for $C O I$ and $10 \%$ for the whole mitogenome) between $A$. exulcerata and its sister-species A. cygnea.

The high genetic divergence between these species was not reflected by any major morphological and/or morphometric differences in the analysed characters. This is probably the reason why A. exulcerata has not been accepted until now, being erroneously assigned either to A. cygnea or A. anatina. Indeed, PCA and DA analyses reveal a broad morphological overlap among Anodonta species, leading to $29 \%$ of specimens being incorrectly assigned in the field. From the results of geometric morphometric analysis, A. cygnea is more easily misidentified with $A$. exulcerata, due to its closer morphological similarity. Anodonta anatina shows the highest percentage of correct assignments by geometric morphometric comparison $(80 \%)$, while A. exulcerata and A. cygnea are confused with each other in more than $28 \%$ of cases. On the contrary, A. cygnea is correctly identified in $80 \%$ of cases when linear biometric characters are used, while A. anatina is more frequently misidentified with $A$. exulcerata. Anodonta cygnea tends to be more laterally compressed and posteriorly pointed, with a more obtuse angle between the dorsal and posterior margin compared to the other two species. Although erosion smoothed the umbonal ornamentation in $64 \%$ of the specimens examined, when visible, this feature can help 
Table 5. Confusion matrix of Discriminant Analysis of 18 Fourier coefficients obtained by Fourier Shape Analysis of Italian Anodonta specimens, showing the proportion of specimens correctly/incorrectly assigned to (A) species [based on 138 specimens and including specimens collected by Nagel (1996)] and (B) site of collection (based on 97 specimens collected by the authors and excluding sites from which fewer than five specimens were available for analysis). Abbreviations: LC, Lake Castel Dell'Alpi; LE, Lake Endine; LL, Lake Levico; LMa, Lake Maggiore; LMo, Lake Montepulciano; LT, Lake Trasimeno

\begin{tabular}{|c|c|c|c|c|c|c|c|c|}
\hline \multirow{2}{*}{$\begin{array}{l}\text { (A) Species } \\
\text { Given group }\end{array}$} & \multicolumn{6}{|c|}{ Predicted group } & \multirow[b]{2}{*}{ Total } & \multirow[b]{2}{*}{$\%$ correct } \\
\hline & \multicolumn{2}{|l|}{ A. anatina } & \multicolumn{2}{|c|}{ A. cygnea } & \multicolumn{2}{|c|}{ A. exulcerata } & & \\
\hline A. anatina & \multicolumn{2}{|l|}{47} & \multicolumn{2}{|l|}{0} & \multicolumn{2}{|l|}{12} & 59 & 80 \\
\hline A. cygnea & \multicolumn{2}{|l|}{1} & \multicolumn{2}{|l|}{13} & \multicolumn{2}{|l|}{8} & 22 & 59 \\
\hline A. exulcerata & \multicolumn{2}{|l|}{10} & \multicolumn{2}{|l|}{9} & \multicolumn{2}{|l|}{38} & 57 & 67 \\
\hline Total & \multirow{2}{*}{\multicolumn{4}{|c|}{$\begin{array}{l}58 \\
\text { Predicted group }\end{array}$}} & \multirow{2}{*}{\multicolumn{2}{|c|}{58}} & 138 & \multirow[t]{2}{*}{71} \\
\hline (B) Sites & & & & & & & & \\
\hline Given group & $\mathrm{LC}$ & $\mathrm{LE}$ & $\mathrm{LL}$ & LMa & LMo & $\mathrm{LT}$ & Total & $\%$ correct \\
\hline $\mathrm{LC}$ & 14 & 1 & 0 & 1 & 0 & 0 & 16 & 88 \\
\hline $\mathrm{LE}$ & 0 & 5 & 0 & 1 & 0 & 0 & 6 & 83 \\
\hline $\mathrm{LL}$ & 0 & 0 & 4 & 0 & 0 & 1 & 5 & 80 \\
\hline $\mathrm{LMa}$ & 3 & 6 & 1 & 39 & 0 & 2 & 51 & 76 \\
\hline LMo & 0 & 0 & 0 & 0 & 10 & 0 & 10 & 100 \\
\hline $\mathrm{LT}$ & 0 & 0 & 1 & 1 & 0 & 7 & 9 & 78 \\
\hline Total & 17 & 12 & 6 & 42 & 10 & 10 & 97 & 81 \\
\hline
\end{tabular}

discriminating between A. cygnea and A. exulcerata . However, umbo sculpture is useless for discriminating A. exulcerata and A. anatina, which present similar double-looped lines.

No clear discriminating character can be identified in the wide and largely overlapping variability of shell shapes of A. anatina, A. cygnea and A. exulcerata, demonstrating once more that shell plasticity evolved as an adaptation to local conditions (e.g. Walker et al., 2001; Hornback et al., 2010; Zieritz et al., 2010; Inoue et al., 2013) hindering the conchological identification of species. This is especially evident in anodontine mussels (Reis et al., 2013; Mezhzherin et al., 2014; Klishko et al., 2018), which display considerable intraspecific shell-shape variation caused by shifts of metabolism at sexual maturity, changes in allometric growth and other physiological characteristics (Zieritz \& Aldridge, 2011; Klishko et al., 2016). Moreover, the morphometric analyses were more powerful in discriminating between sites of collection of the specimens than between species. This result confirms that shell shape is more environmentally than genetically controlled, which is congruent with the hypothesis that phenotypic plasticity, allowing survival in a wide range of environments, could be under positive selection in many freshwater mussel species (Baker et al., 2003; Reis et al., 2013).

Equally, only minimal differences were present in anatomical characters between $A$. exulcerata and the other two species. The easiest-to-use quantitative character is the number of papillae series, which is similar in A. exulcerata and the closely related A. cygnea, but useful to distinguish both species from $A$. anatina. All the other morphological differences shown here are purely qualitative and concern mainly the pigmentation of tissues. Pigmentation is creamy-yellowish in $59 \%$ of A. anatina and $79 \%$ of $A$. exulcerata specimens, while it tends to be brownish in the remaining $41 \%$ and $21 \%$, respectively. The papillae have similar coloration in A. cygnea and A. exulcerata, while those in A. anatina are darker, but the most conspicuous difference is the bright orange pigmentation of the tissues in A. cygnea (100\% of specimens examined). One could argue that the colouring might be excessively tied to external factors to use it as a taxonomic discriminant. However, this distinguishing character was reported for many $A$. cygnea and $A$. anatina populations from other environments and has, therefore, been previously proposed as a character suitable to separate both species (Mordan \& Woodward, 1990; Mezhzherin et al., 2014). Differences in pigmentation seem to be associated with the amount and distribution of orange-yellow extracellular calcified granules in interstitial tissues (Colville \& Lim, 2003). Being determined by anatomical and physiological features, it has been suggested that the distribution of granules may be a useful character for phylogenetic analyses (Byrne, 2000). Furthermore, shell and mantle-edge pigmentation seems to be mainly under genetic control (Brake et al., 2004; Wen et al., 2013), although susceptible to dietaryinduced modifications (Liu et al., 2009). However, unlike the traditionally used conchological characteristics, the plasticity of soft tissue pigmentation is poorly 
documented (e.g. Colville \& Lim,2003; Prié, 2017) and we fail to find any study specifically addressing the variability of this feature in relation to environmental conditions. While the reliability of such qualitative characters remains to be verified, our study provides further evidence that ecophenotypic plasticity hinders shell morphology-based identification. However, despite the variability and overlap of morphometric characters, they better support the separation of $A$. cygnea from A. anatina, than that of $A$. exulcerata from either of the two species. The overlap in morphology and lack of reliable distinctive characters between $A$. exulcerata and A. cygnea could be partially explained by the presence of hybrids. Hybridization has been documented in populations of co-occurring congeneric Pyganodon species in eastern North America that have similar levels of differentiation at COI (9-11\%; Cyr et al., 2007; Doucet-Beaupré et al., 2012) to the difference reported between $A$. exulcerata and $A$. cygnea. Since hybrids are infrequently detected when we sequence m-lineage $C O I$ (Cyr et al., 2007; Zanatta, personal communication), we cannot rule out potential hybridization of intermediate forms of A. exulcerata and A. cygnea. Additionally, it has been shown that $A$. cygnea is typically hermaphroditic, lacking the DUI typical dioecious forms of the F- and M-ORFs within their mitogenomes, but instead have an H-ORF exclusive of hermaphrodite species (Chase et al., 2018). Since A. exulcerata also presents an H-ORF, this strongly suggests that the species is also a true hermaphrodite. If intermediate forms between $A$. cygnea and $A$. exulcerata are the result of hybridization, then it would be between two hermaphroditic species, a topic that has never been addressed and would be interesting to further investigate.

\section{SYSTEMATICS}

Class: Bivalvia Linnaeus, 1758

Order: Unionida Gray, 1854

Family: Unionidae Rafinesque, 1820

Subfamily: Unioninae Rafinesque, 1820

Tribe: Anodontini Rafinesque, 1820

Genus: Anodonta Lamarck 1799

Species: Anodonta exulcerata, 'Villa' Porro, 1838: 111, pl. 2, fig. 12

Common name: fretted anodonta (Sowerby, 1870)

Type locality: 'Nei piccoli laghi di Oggiono, Alserio, e più ancora di Pusiano in Brianza' (In the small lakes of Oggiono (=Lake Annone), Alserio, and even more in Pusiano, Brianza, Italy)

Type: NHMUK1841.5.6.127; Lectotype, here designated.

\section{Chresonymy:}

Anodonta exulcerata 'Villa' Porro, 1838

Anodonta piscinalis exulcerata - Drouët, 1883

Anodonta exulcerata - C. B. Adams, 1847

Margaron (Anodonta) cygnea (Drap.) [in part]

- Lea, 1852

Anodon exulceratus - Sowerby, 1870

Margaron (Anodona) cygnea (Linn).[in part]

- Lea, 1870

Anodonta (Acalliana) exulcerata - Bourguignat, 1881

Anodonta (Acalliana) exulcerata - Bourguignat, 1882

Anodonta exulcerata - Bourguignat, 1883

Anodonta exulcerata - Catlow \& Reeve, 1845; Clessin, 1874

Anodonta (Groupe de l'A. acallia) exulcerata - Locard, 1890

Anodonta (Euanodonta) exulcerata-Westerlund, 1890

Anodonta (Groupe de l'A. acallia) exulcerata - Locard, 1893

Anodonta cygnea (Linnaeus, 1758) [in part] - Simpson, 1900; Simpson, 1914

Anodonta anatina (Linnaeus, 1758) [in part] - Germain, 1931

Anodonta palustris exulcerata - Modell, 1945

Anodonta (Anodonta) cygnea (Linnaeus, 1758) [in part] - Haas, 1969

Anodonta exulcerata - Froufe et al., 2017

Comments: We present only a chresonymy for A. exulcerata and determine the earliest described Anodonta from northern Italy. We have included Anodonta idrina Spinelli, 1851 as the next available taxon for this species. However, due to the confusion of shell forms of $A$. anatina, A. cygnea and A. exulcerata, we have not attempted a complete review of all Anodonta taxa described from Italy in the later part of the $19^{\text {th }}$ and early $20^{\text {th }}$ centuries. This list of taxa includes at least 56 taxa described from Italy (e.g. Alzona, 1971).

Based on the similarity of the shell and on the coincidence of the sampling spots (including one of the type localities, i.e. Lake Oggiono), the rediscovered species was recognized as Anodonta exulcerata, ('Villa') Porro, 1838, using the oldest available name for the Anodonta taxa in the studied region (Haas 1969; Graf \& Cummings, 2019). The shells of the lectotype specimen of $A$. exulcerata deposited in the Natural History Museum, London (NHMUK1841.5.6.127; 
Supporting Information, Fig. S1) and of the paratype specimens from the 'original series' (Zilch, 1967: 111; Senckenberg Museum, $\left.\mathrm{N}^{\circ} 5166\right)$ were analysed in detail before attributing this name to the erroneously synonymized species. Johnson (1971), in reviewing the unionid types in NHMUK, found a specimen labelled Anodon exulceratus and listed it as the specimen from Ziegler figured in Sowerby (1870). Ziegler is listed in the Malacology ledger as the donor of Anodon exulceratus (Dr T. White, pers. comm. 2/4/2019). Sowerby credited the name to a 'Villa' manuscript in the British Museum, indicating that it was Sowerby's figured type. Johnson credited the species description to Sowerby (1870). Sowerby (1870: species 131 page [48], pl. 33 species 131, page 48, plate 33) listed 'Villa. MS in Mus. Brit'. Johnson (1971) cited Anodon exulceratus 'Porro' Sowerby, 1870. Thus, Johnson was aware of the citation of the Villa manuscript by Sowerby, but chose to ignore it and claim it was a Porro manuscript name, ignoring Porro's (1838) description of Anodonta exulcerata. Listing of that specimen figured by Sowerby as the figured holotype represents an inadvertent lectotype fixation under Art. 74.6 of the Code (ICZN, 1999). However, Porro (1838) mentioned in his description 'the plurality of individuals' observed. He also listed three lakes in his distribution. This documents that the description of A. exulcerata by Porro was based on multiple individuals. Thus, the inadvertent lectotype designation by Johnson, (1971) for A. exulcerata 'Porro' Sowerby, 1870 may be valid, but the application of the lectotype to A. exulcerata Porro, 1838 by assumption of holotype is invalid as Porro mentions multiple specimens in his description. This NHMUK specimen, NHMUK 1841.5.6.127 is here designated as the lectotype for Anodonta exulcerata 'Villa' Porro, 1838.

Shell description: Shell generally thin, equivalve and inequilateral, large (max. length $103 \mathrm{~mm}, N=109$ ) elliptical to suboval, moderately inflated. Angle between dorsal margin and posterior margin $124^{\circ}$ to $147^{\circ}\left(\right.$ mean $\left.=135^{\circ}\right)$. Anterior margin broadly rounded, posterior margin narrowly rounded to bluntly pointed; ventral margin convex, occasionally flat straight in the middle nearer to the posterior edge; dorsal margin straight to slightly convex in passing from the posterior margin, occasionally extending into a low dorsal wing; posterior ridge rounded, occasionally weakly biangulated distally; posterior slope moderately steep, flat to slightly convex; umbo broad, moderately inflated, elevated slightly above hinge line; umbo sculpture with thin wavy rugae; umbo cavity wide, shallow. Pseudocardinal and lateral teeth absent. Adductor muscle scars rather light shallow (not deep). Nacre is white to bluish white, usually iridescent. Periostracum tawny to olive or brown; small individuals yellowish brown to dark olive, large individuals brownish black with dark green rays of varying width and intensity. Morphological shell features correspond well to the first description of the species (Porro, 1838) and to the lectotype made available from the Natural History Museum, London (Supporting Information, Fig. S1). One discrepancy lies in the fact that, contrary to what is indicated by Porro, we cannot argue that 'in the majority of individuals the upper and lower margins are parallel, and only in a few individuals are distant posteriorly'. On the contrary, the shape of the shell is so variable that it appears haphazard to draw any generalization (Fig 4; Supporting Information, Fig. S8).

Umbo sculpture also appears to be highly variable, ranging from a clearly double-looped to a finely concentric lines arrangement (Supporting Information, Figs S7S, S9).

Soft anatomy description: In life the mantle is creamy white to yellowish or light-brownish (respectively, 79 and $21 \%$ of individuals examined), brownish or tan at the openings of the apertures, mantle outside of apertures transparent white to grey; visceral mass creamy white to pink powder, may be pale-orange adjacent to foot; foot pale orange to creamy-white.

Gills creamy to gold; dorsal margin sinuous to concave, ventral margin convex; anterior margin of inner gills slightly longer and wider than outer gills. Outer gills marsupial; glochidia held across gill length; well-padded when gravid; light brownish to brownish orange.

Labial palps creamy white; straight to concave dorsally, convex ventrally, pointed distally; with a smooth external surface and a finely canaliculated internal surface.

Incurrent aperture longer than excurrent and supraanal apertures; supra-anal and incurrent apertures occasionally of similar length. Incurrent aperture creamy white to grey within; greyish or brownish basal to papillae; papillae in two to three rows, inner row usually larger, longer, thick; papillae white-creamy to light tan; whitish in living animals. Excurrent aperture smooth, whitish at the external margin, with darkly coloured irregular band at the base. Supraanal aperture smooth, creamy white within, without marginal coloration.

Voucher specimens: Six voucher specimens of this species were deposited: two at the Museo de La Specola-Florence (catalogue numbers: MZUF $\mathrm{BC} / 51405$ and MZUF BC/51406), two at the Naturhistorisches Museum der Burgergemeinde Bern (NMBE 549733 and NMBE 549734) and two 
at the North Carolina Museum of Natural Sciences (NCSM 102851 and NCSM 102852) (Table 5; Froufe et al., 2017). Since Anodonta exulcerata Porro, 1838 is the oldest available name for the Anodonta taxa in the studied region (Haas, 1969; Graf \& Cummings 2019), A. exulcerata is used herein for this newly detected Anodonta species. The shell morphology of A. exulcerata specimens sampled in this study (Supporting Information, Fig. S3) is consistent with the lectotype of A. exulcerata (Natural History Museum, UK: Lectotype NMNHUK 1841.5.6.127) and with the paratype specimens of the Senckenberg Museum, Frankfurt am Main (Zilch, 1967). Furthermore, in one of its type localities (Lake Annone), it was the only Anodonta species found (Froufe et al., 2017).

Distribution: Anodonta exulcerata is found from the Italian Peninsula to Croatia west of the Dinaric Alps (Froufe et al., 2017), which confirms the distribution reported by Clessin (1876). In northern Italy it appears to be the most common Anodonta species.

Habitat and biology: Anodonta exulcerata occur in waters with little or no current and substrates typically composed of mud or muddy sand, often with detritus. Due to misidentification with other Anodonta species, information on biology is scarce. Gravid individuals brooding glochidia at different stages of development have been observed from early September to late December in Lake Maggiore and Lake Varese (N. Riccardi, pers. obs.). Glochidial host fish species are unknown.

Conservation status: The fact that A. exulcerata has not been previously recognized has precluded any assessment of its conservation status. However, it is widely distributed in the region and locally abundant, which might suggest that currently the species is not at risk.

Comparison with similar species: Close conchological similarity and wide shell plasticity make the use of shell shape for the discrimination of A. exulcerata from coexisting congeneric species (i.e. A. anatina and A. cygnea) unreliable. Like A. anatina, $A$. exulcerata tends to be more swollen than A. cygnea slightly posterior to the umbo. However, the difference, whenever it exists, may be masked by the broad shell plasticity. Indeed, except for the index of convexity standardized over length, the mean values of the shell measurement ratios were not significantly different (Table 2). To the extent that reliable external features could be identified to distinguish the two central, northern and eastern European Anodonta species (Gallenstein
1895, Möller 1933, Bloomer 1937, Franz 1939), it also became apparent that the Italian forms could not be clearly identified (Gallenstein 1894, Falkner 1994). Rather, a mixture of the otherwise species-specific characteristics was often found. Only the analysis of further characters (allozymes, DNA) contributed a new view on this problem providing an objective basis to older assumptions about the peculiarities of the Italian unionid fauna.

Clessin (1874) already stressed the close similarity of $A$. exulcerata and A. anatina ('belongs to the Formenkreis of Anodonta anatina Rossm') and attributed $A$. exulcerata, as well as the similar A. idrina (Spinelli, 1851), to the A. anatina 'group'. Kobelt (1876) reiterated that A. idrina, A. exulcerata and A. gibba (a nomen nudum) should not be separated, and emphasizes the enormous difficulties and uncertainties in distinguishing the species of Anodonta. This is the only final message to be drawn after getting lost in the enormous variety of conflicting opinions among malacologists of the time.

For the determination of live animals or shells in the field, a diagnosis based on external characters is highly desirable. For this purpose, a larger number of molecularly determined forms must be examined anatomically and conchologically. This step is reserved for future investigation.

\section{ACKNOWLEDGEMENTS}

Dr Thomas White, curator of mollusks, Natural History Museum, London, is thanked for his assistance in helping with the history of the lectotype of Anodonta exulcerata Porro, 1838. Mr Jonathan Ablett, mollusks, Natural History Museum, London, assisted us with pictures of the lectotype. Revision and editing of a draft of this manuscript was done during the Fulbright Scholarship to A. E. Bogan, 2019, Porto, Portugal. We also thank the reviewers, David Zanatta and Ilya Vikhrev, for valuable comments on the manuscript.

\section{FUNDING}

This research was developed under ConBiomics: the missing approach for the conservation of freshwater bivalves project $\mathrm{N}^{\circ}$ NORTE-01-0145-FEDER-030286, cofinanced by COMPETE 2020, Portugal 2020 and the European Union through the ERDF - European Regional Development Fund and by FCT - Fundação para a Ciência e a Tecnologia, through national funds (UID/Multi/04423/2019). FCT also supported Manuel Lopes-Lima (SFRH/BD/115728/2016). 


\section{REFERENCES}

Alzona C. 1971. Malacofauna Italica. Catalogo e bibliografia dei molluschi viventi, terrestri e d'acqua dolce. Atti della Società Italiana di Scienze Naturali e del Museo Civico di Storia Naturale di Milano 111: 1-433.

Autorità di Bacino dei fiumi dell'Alto Adriatico, 2010. Piano di gestione dei bacini idrografici delle Alpi Orientali. 05. : Bacino del fiume Sile. Available at: http://www.alpiorientali. it/documenti/list_doc/pub/PdP_doc/05_PG_sile_2010_02_24.pdf

Baker AM, Bartlett C, Bunn SE, Goudkamp K, Sheldon F, Hughes JM. 2003. Cryptic species and morphological plasticity in long-lived bivalves (Unionoida: Hyriidae) from inland Australia. Molecular Ecology 12: 2707-2717.

Blevins E, Jepsen S, Brim Box J, Nez D, Howard J, Maine A, O'Brien C. 2017. Extinction risk of western North American freshwater mussels: Anodonta nuttalliana, the Anodonta oregonensis / kennerlyi clade, Gonidea angulata, and Margaritifera falcata. Freshwater Mollusk Biology and Conservation 20: 71-88.

Bloomer HH. 1937. On distinguishing the shell of Anodonta cygnea from that of Anodonta anatina. Journal of Conchology 20: $321-327$.

Bodon M, Cianfanelli S, Manganelli G, Castagnolo L, Pezzoli E, Giusti F. 2005. Mollusca Bivalvia. In: Ruffo S, Stoch F, eds. Checklist e distribuzione della fauna italiana. 10.000 specie terrestri e delle acque interne. Verona: Memorie del Museo Civico di Storia Naturale di Verona, 2. serie. Sezione Scienze della Vita 16: 83-84.

Bogan AE. 1993. Freshwater bivalve extinctions: search for a cause. American Zoologist 33: 599-609.

Boggero A, Pierri C, Alber R, Austoni M, Barbone E, Bartolozzi L, Bertani I, Campanaro A, Cattaneo A, Cianferoni F, Colangelo P, Corriero G, Martin Dörr A, Elia AC, Ficetola GF, Fontaneto D, Gaino E, Goretti E, Kamburska L, La Porta G, Lauceri R, Lorenzoni M, Ludovisi A, Manca M, Morabito G, Nonnis Marzano F, Oggioni A, Riccardi N, Rossetti G, Tagliolato P, Thaler B, Ungaro N, Volta P, Zaupa S, Rosati I, Fiore N, Basset A, Marchetto A. 2016. A geographic distribution dataset of biodiversity in Italian freshwaters. Biogeographia - The Journal of Integrative Biogeography 31: 55-72.

Bon M, Mezzavilla F. 2000. Parco Regionale Naturale del Fiume Sile - Piano ambientale: relazione di analisi settore faunistico - invertebrati-uccelli-mammiferi. Venice: Piano ambientale del Parco del fiume Sile. Available at: https:// www.vedelago.gov.it/comune/Servizi-on-line/Regolamenti/

Brake J, Evans F, Langdon C. 2004. Evidence for genetic control of pigmentation of shell and mantle edge in selected families of Pacific oysters, Crassostrea gigas. Aquaculture 229: 89-98.

Breton S, Stewart DT, Shepardson SP, Trdan RJ, Bogan AE, Chapman EG, Ruminas AJ, Piontkivska H, Hoeh WR. 2011. Novel protein genes in animal mtDNA: a new sex determination system in freshwater mussels (Bivalvia: Unionoida)? Molecular Biology and Evolution 28: 1645-1659.

Byrne M. 2000. Calcium concretions in the interstitial tissues of the Australian freshwater mussel Hyridella depressa
(Hyriidae). In: Harper EM, Taylor JD, Crame JA, eds. The evolutionary biology of the Bivalvia. London: Geological Society, Special Publications, 29-43.

Chase EE, Robicheau BM, Veinot $\mathbf{S}$, Breton $\mathbf{S}$, Stewart DT. 2018. The complete mitochondrial genome of the hermaphroditic freshwater mussel Anodonta cygnea (Bivalvia: Unionidae): in silico analyses of sex-specific ORFs across order Unionoida. BMC Genomics 19: 221.

Chong JP, Brim-Box JC, Howard JK, Wolf D, Myers TL, Mock KE. 2008. Three deeply divided lineages of the freshwater mussel genus Anodonta in western North America. Conservation Genetics 9: 1303-1309.

Clement M, Posada D, Crandall KA. 2000. TCS: a computer program to estimate gene genealogies. Molecular Ecology 9: 1657-1659.

Clessin S. 1873-1876 [1874]. Die Gattung Anodonta nebst den übrigen Najaden mit unvollkommenem Schloss. In: Küster HC, Clessin S, eds Abbildungen nach der Natur mit Beschreibungen. Systematisches Conchylien-Cabinet von Martini und Chemnitz Band 9, Abteilung 1. Nürnberg: Verlag von Bauer \& Raspe.

Conant GC, Wolfe KH. 2008. GenomeVx: simple webbased creation of editable circular chromosome maps. Bioinformatics 24: 861-862.

Cosolo M. 2008. Nuovo piano di assetto del territorio, comune di Vedelago, allegato B: analisi faunistica. 55. Available at: http://www.parcosile.it/pagina.php?id=97

Colville AE, Lim RP. 2003. Microscopic structure of the mantle and palps in the freshwater mussels Velesunio ambiguus and Hyridella depressa (Bivalvia: Hyriidae). Molluscan Research 23: $1-20$.

Crampton JS, Haines AJ. 1996. Users' manual for programs HANGLE, HMATCH and HCURVE for the Fourier shape analysis of two-dimensional outlines. Lower Hutt, NZ: Institute of Geological and Nuclear Sciences Science Report 96/37, 1-28.

Cyr F, Paquet A, Martel AL, Angers B. 2007. Cryptic lineages and hybridization in freshwater mussels of the genus Pyganodon (Unionidae) in northeastern North America. Canadian Journal of Zoology 85: 1216-1227.

Doucet-Beaupré H, Blier P, Chapman EG, Piontkivska H, Dufresne F, Sietman BE, Mulcrone RS, Hoeh WR. 2012. Pyganodon (Bivalvia: Unionoida: Unionidae) phylogenetics: a male- and female-transmitted mitochondrial DNA perspective. Molecular Phylogenetics and Evolution 63: 430-444.

Falkner G. 1994. Systematik vorderorientalischer Najaden als Vorstudie zur Bearbeitung archäologischer Funde. In: Kokabi M, Wahl J, eds. Beiträge zur Archäozoologie und Prehistorischen Anthropologie. Forschungen und Berichte zur Vor- und Frühgeschichte in Baden-Württemberg 53: 135-162. Ferreira-Rodríguez N, Akiyama YB, Aksenova OV, Araujo R, Barnhart MC, Bespalaya YV, Bogan AE, Bolotov IN, Budha PB, Clavijo C, Clearwater SJ, Darrigran G, Do VT, Douda K, Froufe E, Gumpinger C, Henrikson L, Humphrey CL, Johnson NA, Klishko O, Klunzinger MW, Kovitvadhi S, Kovitvadhi U, Lajtner J, Lopes-Lima M, Moorkens EA, Nagayama S, Nagel K-O, Nakano M, Negishi JN, Ondina P, Oulasvirta P, Prié V, 
Riccardi N, Rudzīte M, Sheldon F, Sousa R, Strayer DL, Takeuchi M, Taskinen J, Teixeira A, Tiemann JS, Urbańska M, Varandas S, Vinarski MV, Wicklow BJ, Tadeusz Zając T, Vaughn CC. 2019. Research priorities for freshwater mussel conservation assessment. Biological Conservation 231: 77-87.

Fonseca MM, Lopes-Lima M, Eackles MS, King TL, Froufe E. 2016. The female and male mitochondrial genomes of Unio delphinus and the phylogeny of freshwater mussels (Bivalvia: Unionida). Mitochondrial DNA Part B Resources 1: 954-957.

Franz V. 1939. Die Unterscheidung der zwei mitteleuropäischen Anodonta-Arten cygnea (L.) und piscinalis NILSS. und die Haupttypen derselben. Jenaische Zeitschrift für Naturwissenschaften 72: 75-210.

Froufe E, Sobral C, Teixeira A, Sousa R, Varandas S, Aldridge D, Lopes-Lima M. 2014. Genetic diversity of the pan-European freshwater mussel Anodonta anatina (Bivalvia: Unionoida) based on CO1: new phylogenetic insights and implications for conservation. Aquatic Conservation: Marine and Freshwater Ecosystems 24: 561-574.

Froufe E, Gan HM, Lee YP, Carneiro J, Varandas S, Teixeira A, Zieritz A, Sousa R, Lopes-Lima M. 2016. The male and female complete mitochondrial genome sequences of the endangered freshwater mussel Potomida littoralis (Cuvier, 1798) (Bivalvia: Unionidae). Mitochondrial DNA Part A 27: 3571-3572.

Froufe E, Lopes-Lima M, Riccardi N, Zaccara S, Vanetti I, Lajtner J, Teixeira A, Varandas S, Prié V, Zieritz A, Sousa R, Bogan AE. 2017. Lifting the curtain on the freshwater mussel diversity from the Italian Peninsula and Croatian Adriatic coast. Biodiversity and Conservation 26: 3255-3274.

Froufe E, Bolotov I, Aldridge DC, Bogan AE, Breton S, Gan HM, Kovitvadhi U, Kovitvadhi S, Riccardi N, SecciPetretto G, Sousa R, Teixeira A, Varandas S, Zanatta D, Zieritz A, Fonseca MM, Lopes-Lima M 2019. Mesozoic mitogenome rearrangements and freshwater mussel (Bivalvia: Unionoidea) macroevolution. Heredity, https://doi. org/10.1038/s41437-019-0242-y (accessed 30 June 2019).

Gallenstein HTR v. 1894. Studien zur Najadenfauna des Isonzogebietes. Jahresbericht der Staats-Oberrealschule in Görz 34: 5-49.

Gallenstein HTR v. 1895. Die Bivalven- und Gastropodenfauna Kärntens; I. Bivalven. Jahrbuch des Naturhistorischen Museums von Kärnten 23: 1-67.

Gan H, Schultz MB, Austin CM. 2014. Integrated shotgun sequencing and bioinformatics pipeline allows ultrafast mitogenome recovery and confirms substantial gene rearrangements in Australian freshwater crayfishes. BMC Evolutionary Biology 14: 19.

Glöer P, Meier-Brook C. 2003. Süßwassermollusken. Ein Bestimmungsschlüssel für die Bundesrepublik Deutschland, 13th edn. Hamburg: Deutscher Jugendbund für Naturbeobachtung, 134.

Graf D, Cummings K. 2019. The MUSSEL Project Database. Available at: <http://musselproject.uwsp.edu/db/> (accessed 19 March 19).
Guarneri I, Popa OP, Gola L, Kamburska L, Lauceri R, Lopes-Lima M, Popa LO, Riccardi N. 2014. A morphometric and genetic comparison of Sinanodonta woodiana (Lea, 1834) populations: does shape really matter? Aquatic Invasions 9: 183-194.

Haas F. 1969. Superfamilia Unionacea. In: Martens R, Hennig W, eds. Das Tierreich. Berlin: Walter de Gruyter, 88: 1-663.

Hammer Ø, Harper DAT. 2006. PAST version 1.57. Oslo: Natural History Museum, University of Oslo, Norway. Available at: http://folk.uio.no/ohammer/past/ (accessed 1 July 19).

Hornback DJ, Kurth VJ, Hove MC. 2010. Variation in freshwater mussel shell sculpture and shape along a river gradient. American Midland Naturalist 164: 22-36.

ICZN. 1999. International Code of Zoological Nomenclature, 4th edn. London: International Trust for Zoological Nomenclature. Available at: http://www.iczn.org/ (accessed 1 July 19).

Inoue K, Hayes DM, Harris JL, Christian AD. 2013. Phylogenetic and morphometric analyses reveal ecophenotypic plasticity in freshwater mussels Obovaria jacksoniana and Villosa arkansasensis (Bivalvia: Unionidae). Ecology and Evolution 3: 2670-2683.

Johnson RI. 1971. The types and figured specimens of Unionacea (Mollusca: Bivalvia) in the British Museum (Natural History). Bulletin of the British Museum (Natural History) Zoology 20: 75-108.

Katoh K, Standley DM. 2013. MAFFT multiple sequence alignment software version 7: improvements in performance and usability. Molecular Biology and Evolution 30: 772-780.

Klishko OK, Lopes-Lima M, Froufe E, Bogan AE, Abakumova VY. 2016. Systematics and distribution of Cristaria plicata (Bivalvia, Unionidae) from the Russian Far East. ZooKeys 580: 13-27.

Klishko OK, Lopes-Lima M, Bogan AE, Matafonov DV, Froufe E. 2018. Morphological and molecular analyses of Anodontinae species (Bivalvia, Unionidae) of Lake Baikal and Transbaikalia. PLoS One 13: e0194944.

Kobelt W. 1876. Iconographie der Land-und SüsswasserMollusken mit vorzüglicher Berücksichtigung der europäischen noch nicht abgebildeten Arten von E.A. Rossmässler, fortgesetzt von Dr. W. Kobelt. Wiesbaden: CW Kreidel's Verlag.

Kumar S, Stecher G, Tamura K. 2016. MEGA7: molecular evolutionary genetics analysis version 7.0 for bigger datasets. Molecular Biology and Evolution 33: 1870-1874.

Lanfear R, Frandsen PB, Wright AM, Senfeld T, Calcott B. 2016. PartitionFinder 2: new methods for selecting partitioned models ofevolution for molecular and morphological phylogenetic analyses. Molecular Biology and Evolution 34: 772-773.

Librado P, Rozas J. 2009. DnaSP v5: a software for comprehensive analysis of DNA polymorphism data. Bioinformatics 25: 1451-1452.

Liu X, Wu FC, Zhao HE, Zhang GF, Guo XM. 2009. A novel shell color variant of the Pacific abalone Haliotis discus Hannai Ino subject to genetic control and dietary influence. Journal of Shellfish Research 28: 419-424. 
Lopes-Lima M, Sousa R, Geist J, Aldridge DC, Araujo R, Bergengren J, Bespalaja Y, Bódis E, Burlakova L, Van Damme D, Douda K, Froufe E, Georgiev D, Gumpinger C, Karatayev A, Kebapçi Ü, Killeen I, Lajtner J, Larsen BM, Lauceri R, Legakis A, Lois S, Lundberg S, Moorkens E, Motte G, Nagel K-O, Ondina P, Outeiro A, Paunovic M, Prié V, Von Proschwitz T, Riccardi N, Rudzīte M, Rudzītis M, Scheder C, Seddon M, Sereflisan H, Simić V, Sokolova S, Stoeckl K, Taskinen J, Teixeira A, Thielen F, Trichkova T, Varandas S, Vicentini H, Zajac K, Zajac T, Zogaris S. 2017a. Conservation status of freshwater mussels in Europe: state of the art and future challenges. Biological Reviews 92: 572-607.

Lopes-Lima M, Froufe E, Do Tu V, Ghamizi M, Mock KE, Kebapçi Ü, Klishko O, Kovitvadhi S, Kovitvadhi U, Paulo OS, Pfeiffer JM III, Raley M, Riccardi N, Şereflişan H, Sousa R, Teixeira A, Varandas S, Wu X, Zanatta DT, Zieritz A, Bogan AE 2017b. Phylogeny of most species rich freshwater bivalve family (Bivalvia: Unionida: Unionidae): defining modern subfamilies and tribes. Molecular Phylogenetics and Evolution 106: 174-191.

Lopes-Lima M, Fonseca MM, Aldridge DC, Bogan AE, Gan HM, Ghamizi M, Sousa R, Texeira A, Varandas S, Zanatta D, Zieritz A, Froufe E. 2017c. The first Margaritiferidae male (M-type) mitogenome: mitochondrial gene order as a potential character for determining higherorder phylogeny within Unionida (Bivalvia). Journal of Molluscan Studies 83: 249-252.

Lopes-Lima M, Burlakova LE, Karatayev AY, Mehler K, Seddon M, Sousa R. 2018. Conservation of freshwater bivalves at the global scale: diversity, threats and research needs. Hydrobiologia 810: 1-14.

McCormack JE, Hird SM, Zellmer AJ, Carstens BC, Brumfield RT. 2013. Applications of next-generation sequencing to phylogeography and phylogenetics. Molecular Phylogenetics and Evolution 66: 526-538.

Mezhzherin SV, Yanovich LM, Zhalay EI, Vasilieva LA, Pampura MM. 2014. Genetic and morphological variability and differentiation of freshwater mussels (Bivalvia, Unionidae, Anodontinae) in Ukraine. Vestnik Zoologii 48: 99-110.

Möller H. 1933. Artunterschiede der deutschen Anodonten. Jenaische Zeitschrift für Naturwissenschaften 66: 481-534.

Mordan PB, Woodward FR. 1990. Case 1643. Mytilus anatinus, Linnaeus, 1758 (currently Anodonta anatina; Mollusca: Bivalvia) proposed designation of a neotype. Bulletin of Zoological Nomenclature 47: 110-113.

Nagel K-O, Badino O, Alessandria B. 1996. Population genetics of European Anodontinae (Bivalvia: Unionidae). Journal of Molluscan Studies 62: 343-357.

Naimo TJ, Damschen ED, Rada RG, Monroe EM. 1998. Nonlethal evaluation of the physiological health of unionid mussels: methods for biopsy and glycogen analysis. Journal of the North American Benthological Society 17: 121-128.

Pfeiffer JM, Breinholt JW, Page LM, 2019. Unioverse: a phylogenomic resource for reconstructing the evolution of freshwater mussels (Bivalvia, Unionoida). Molecular Phylogenetics and Evolution 137: 114-126.

Porro C. 1838. Malacologia terrestre e fluviale della Provincia Comasca. Milano: Tipografia Guglielmini e Redaelli, 132.

Prié V. 2017. Naïades et autres bivalves d'eau douce de France. Paris: Biotope, Mèze, Muséum national d'Histoire naturelle (collection inventaires \& biodiversité), 336 .

Prié V, Puillandre N, Bouchet P. 2012. Bad taxonomy can kill: molecular reevaluation of Unio mancus Lamarck, 1819 (Bivalvia: Unionidae) and its accepted subspecies. Knowledge and Management of Aquatic Ecosystems 405: 08p1-08p18; DOI: $10.1051 / \mathrm{kmae} / 2012014$.

Rasband W. 2008. ImageJ. Image processing and analysis in Java. Bethesda: National Institutes of Health, USA. Available at: http://rsbweb.nih.gov/ij (accessed 1 July 19).

Ratnasingham S, Hebert PDN. 2013. A DNA-based registry for all animal species: the barcode index number (BIN) system. PLoS One 8: e66213.

Reis J, Machordom A, Araujo R. 2013. Morphological and molecular diversity of Unionidae (Mollusca, Bivalvia) from Portugal. Graellsia 69: 17-36.

Ronquist F, Teslenko M, Van der Mark P, Ayres DL, Darling A, Höhna S, Larget B, Liu L, Suchard MA, Huelsenbeck JP. 2012. MrBayes 3.2: efficient Bayesian phylogenetic inference and model choice across a large model space. Systematic Biology 61: 539-542.

Rossmässler EA. 1835. Iconographie der Land-und Süsswasser-Mollusken, mit vorzüglicher Berücksichtigung der europäischen noch nicht abgebildeten Arten. Dresden \& Leipzig: Arnoldische Buchhandlung.

Sambrook J, Fritsch EF, Maniatis T. 1989. Molecular cloning. A laboratory manual. Cold Spring Harbor, NY: Cold Spring Harbor Laboratory Press.

Sayenko EM. 2007. New data on soft parts morphology of the anodontine bivalves from Russia [in Russian]. Bulletin of the Russian Far East Malacological Society 11: 100-106.

Sayenko EM, Bogatov VV, Zaykin DV. 2009. On the systematic position of the Far Eastern genera Kunashiria and Arsenievinaia (Bivalvia, Unionidae) [in Russian]. Zoologicheskyi zhurnal 88: 1298-1310.

Schwarz G. 1978. Estimating the dimension of a model. Annals of Statistics 6: 461-464.

Sela I, Ashkenazy H, Katoh K, Pupko T. 2015. GUIDANCE2: accurate detection of unreliable alignment regions accounting for the uncertainty of multiple parameters. Nucleic Acids Resources 43: W7-W14.

Shea CP, Peterson JT, Wisniewski JM, Johnson NA. 2011. Misidentification of freshwater mussel species (Bivalvia: Unionidae): contributing factors, management implications, and potential solutions. Journal of the North American Benthological Society 30: 446-458.

Simpson CT. 1900. Synopsis of the naiades, or pearly freshwater mussels. Proceedings of the United States National Museum 22: 501-1044.

Simpson CT. 1914. A descriptive catalogue of the naiades, or pearly freshwater mussels. Parts I-III. Detroit: Bryant Walker. 
Smith CH, Johnson NA, Pfeiffer JM, Gangloff MM. 2018. Molecular and morphological data reveal non-monophyly and speciation in imperiled freshwater mussels (Anodontoides and Strophitus). Molecular Phylogenetics and Evolution 119: $50-62$.

Sowerby GB. 1870. Genus Anodon. Conchologica Iconica 17: 25-37.

Spinelli GB. 1851. Catalogo dei molluschi terrestri e fluviali della Provincia Bresciana. Brescia: Tipografia Francesco Speranza.

Stamatakis A. 2014. RAxML version 8: a tool for phylogenetic analysis and post-analysis of large phylogenies. Bioinformatics 30: 1312-1313.

Vaughn CC. 2018. Ecosystem services provided by freshwater mussels. Hydrobiologia 810: 15-27.

Wen H, Gu R, Cao Z, Zhou X, Nie Z, Ge X, Xu P, Hua D. 2013. Variation of color and ray pattern in juvenile shells in hatchery-produced freshwater triangle pearl mussels, Hyriopsis cumingii, in China. Journal of the World Aquaculture Society 44: 154-160.

Williams JD, Bogan AE, Butler RS, Cummings KS, Garner JT, Harris JL, Johnson NA, Watters GT. 2017. A revised list of the freshwater mussels (Mollusca: Bivalvia: Unionida) of the United States and Canada. Freshwater Mollusk Biology and Conservation 20: 35-58.
Zhang J, Kapli P, Pavlidis P, Stamatakis A. 2013. A general species delimitation method with applications to phylogenetic placements. Bioinformatics 29: 2869-2876.

Zieritz A, Aldridge DC. 2009. Identification of ecophenotypic trends within three European freshwater mussel species (Bivalvia: Unionoida) using traditional and modern morphometric techniques. Biological Journal of the Linnean Society 98: 814-825.

Zieritz A, Aldridge DC. 2011. Sexual, habitat-constrained and parasite-induced dimorphism in the shell of a freshwater mussel (Anodonta anatina, Unionidae). Journal of Morphology 272: 1365-1375.

Zieritz A, Hoffman JI, Amos W, Aldridge DC. 2010. Phenotypic plasticity and genetic isolation-by-distance in the freshwater mussel Unio pictorum (Mollusca: Unionoida). Evolutionary Ecology 24: 923-938.

Zieritz A, Bogan A, Froufe E, Klishko O, Kondo T, Kovitvadhi U, Kovitvadhi S, Lee JH, Lopes-Lima M, Pfeiffer JM, Sousa R, Van Do T, Vikhrev I, Zanatta DT. 2018. Diversity, biogeography and conservation of freshwater mussels (Bivalvia: Unionida) in East and Southeast Asia. Hydrobiologia 810: 29-44.

Zilch A. 1967. Die Typen und Typoide des Natur-Museums Seckenberg, 39:1), Mollusca, Unionacea. Archiv für Molluskenkunde 97: 45-154.

\section{SUPPORTING INFORMATION}

Additional Supporting Information may be found in the online version of this article at the publisher's web-site.

Figure S1. Lectotype of Anodonta exulcerata - N 1841.5.6.127, Natural History Museum, London.

Figure S2. Paratypes of Anodonta exulcerata - $\mathrm{N}^{\circ} 5166$, Senckenberg Museum of Natural History, Frankfurt am Main.

Figure S3. Representative specimens of Anodonta exulcerata collected in Lake Maggiore, at location Monvalle, Gureé beach close to the reeds belt (left and center), and at location Magadino, inside the Porto Patriziale (right). Figure S4. Aspect of excurrent aperture and papillae in living (left) and freshly dissected (right) A. anatina (top), A. exulcerata (intermediate) and A. cygnea (bottom).

Figure S5. Arrangement of papillae in A. anatina (left), A. exulcerata (centre) and A. cygnea (right).

Figure S6. Coloration of soft tissues in freshly dissected A. anatina (left), A. exulcerata (center) and A. cygnea (right).

Figure S7. Umbonal sculpture of A. anatina $(A a)$, A. exulcerata $(A e)$ and $A$. cygnea $(A c)$. LT = Lake Trasimeno; LCA = Lake Castel dell'Alpi; LC = Lake Caldonazzo; LL = Lake Levico; LMA = Lake Maggiore; LMO = Lake Montepulciano; LLU = Lake Lugano.

Figure S8. Variability of shell shape of A. exulcerata specimens.

Figure S9. Variability of umbo sculpture in A. anatina (Aa), A. exulcerata (Ae) and A. cygnea (Ac) specimens. LT = Lake Trasimeno; LCA = Lake Castel dell'Alpi; LC = Lake Caldonazzo; LL = Lake Levico; LMA = Lake Maggiore; LMO = Lake Montepulciano; LLU = Lake Lugano.

Table S1. List of specimens analysed for the mitogenomes, GenBank references and country. *original identification.

Table S2. List of all individual haplotypes, species and GenBank accession codes.

Table S3. Main structural features of mitochondrial genomes from newly sequenced specimens. 